\title{
DIGESTIBILITY AND HEMATOLOGICAL PARAMETERS OF BROILER CHICKENS FED BLOOD MEAL AS A REPLACEMENT FOR SYNTHETIC LYSINE
}

\author{
E. K. NDELEKWUTE, H. O. UZEGBU AND L. S. ABDU
}

(Received 7, August 2008; Revision Accepted 24, November 2008)

\begin{abstract}
An experiment was carried out to determine the effect of replacing synthetic lysine (SL) with blood meal (BM) on apparent nutrients digestibility and hematological responses of broiler chickens. One hundred and fifty (150) unsexed Anak broiler chicks were used. There were five diets with diet $\left(T_{1}\right)$ containing $0.10 \% \mathrm{SL}$ and without BM as control. Diets 2, 3, 4 and 5 contained 1.0, 2.0, 3.0 and 4.0\% BM without SL respectively, representing $T_{2}, T_{3}, T_{4}$ and $T_{5}$ in the same order. The experiment was arranged in completely randomized design (CRD) with three replicates per treatment. Each treatment had 30 birds, 10 birds per replicate. Diets were isonitrogenous (23\%CP and $20 \% \mathrm{CP})$ for starter and finisher phases and isocaloric (11.90MJME/Kg and $12.30 \mathrm{MJME} / \mathrm{Kg}$ ) for starter and finisher phases respectively. At the end of the experiment which lasted for 56 days (28 days for each phase), $4.0 \%$ BM significantly $(P<0.05)$ reduced protein digestibility at both phases and $3.0 \%$ at starter phase only. Other nutrients digestibility and hematological parameters (white blood cells, red blood cells, hemoglobin and packed cell volume) measured were not significantly $(P>0.05)$ different at both phases. There was no mortality recorded in all the dietary groups.
\end{abstract}

KEYWORDS: Lysine, blood meal, hematological, digestibility, broilers.

\section{INTRODUCTION}

Broiler chickens remain the fastest source of animal protein because of their rapid growth. This is due to their improved genetic make up, good nutrition and adequate management. This rapid growth may be hampered by poor nutrition emanating from poor feeds necessitated by high cost of feed ingredients. However, Uzegbu et al. (2007) noted that as the cost of the major feedstuff continues to progressively increase, there is still the need to maximize productivity. But maximization of productivity in broilers in form of heavy body weight with economical feed intake, is only achievable through the amount of good quality nutrients that are digested, absorbed and utilized by birds (Ndelekwute 2004).To achieve this, synthetic lysine is routinely added to chicken diets, because cereal grains and vegetable proteins which form the larger proportion of the diets contain limited lysine (D'Mello, 1993), and a major portion of the natural lysine in these plant feedstuffs are not available to the chicks (Prieto et al., 1994).However, since Odukwe and Njoku (1987) reported that synthetic lysine was imported and expensive in Nigeria this has not changed and increase in price has become more progressive currently. This may continue as local production of this essential feed ingredient is not yet in place. Therefore, to cushion this the need to look for feed ingredient that is available locally, less expensive that is good source of lysine is necessary. Blood meal is a good source of protein and lysine with $80 \%$ protein (Olomu, 1995) and 7\% lysine (Donkoh et al., 1999). Blood used to prepare blood meal is available in sufficient quantity in Nigeria (Awonorin et al., 1991).
The objective of this study therefore was to compare the effect of replacement of $0.10 \%$ synthetic lysine with blood meal in broiler diets on nutrients digestibility and hematological parameters.

\section{MATERIALS AND METHODS}

\section{Experimental Site}

The experiment was conducted at the Teaching and Research Farm of College of Animal Science and Animal Production, Michael Okpara University of Agriculture, Umudike Abia State. Umudike is located at latitude $5^{0} 29^{1} \mathrm{~N}$ and longitude $7^{0} 32^{1} \mathrm{E}$ in the rainforest zone of Nigeria with average relative humidity of $72 \%$. It has average rainfall of $2000 \mathrm{~mm}$ per annum with double maxima pattern.

\section{Procurement and Processing of Blood Meal}

Cattle blood used to process into the used blood meal was obtained from a government abattoir about $15 \mathrm{~km}$ from the site of the experiment. The blood was cooked in a 30 litres capacity aluminium pot over a fire wood. It was allowed to boil for 20 minutes after which pot content was then transferred into a Hessian sack. The sack and boiled bloodwas pressed to reduce the water content. Blood lumps formed were then spread on a clean mat under the sun for drying. Mosquito net raised to one meter high was used to cover the spread lumps to avoid perching of flies on the lumps and hence to avoid contamination. It took three days to dry under average ambient temperature of 34 decrees Celsius. The dry blood was then ground into a meal. Proximate composition and amino acid profile of the blood meal were determined according to AOAC (1984) table 1. 


\section{Experimental Diets}

Five diets were produced using trial and error method (Olomu, 1995) for both starter and finisher phases. Diet 1 which contained $0.10 \%$ synthetic lysine without blood meal served as control. Diets 2, 3, 4 and 5 respectively contained 1.0, 2.0, 3.0 and $4.0 \%$ blood meal calculated to supply $0.07,0.14,0.21$ and $0.28 \%$ bound lysine respectively without synthetic lysine. All diets were made isonitrogenous, $23 \%$ for starter diets and $20 \%$ for finisher diets, and isocaloric, 11.90MJME/Kg for starter and $12.30 \mathrm{MJME} / \mathrm{Kg}$ for finisher diets as shown in table 2.

\section{Experimental Chicks and Design}

Completely randomized design (CRD) was used in this study. One hundred and fifty unsexed day old chicks of Anak Strain obtained from hatchery agent were used.The experiment started from day one. Birds were randomly grouped into dietary treatments with 30 birds per treatment. Each treatment was replicated three times with 10 birds per replicate. Brooding was the conventional floor system with stove as source of heat placed under a hover for each treatment. Birds were both fed and watered unrestricted, and were vaccinated against Newcastle and Gumboro diseases. Antibiotic drugs were periodically given as preventive measures.

\section{Data Collection and Analysis Digestibility Study.}

At the end of each phase, fecal samples were collected from birds for digestibility studies. Five days to the end of each phase, two birds from each replicate of a treatment giving a total of six birds per treatment, were randomly selected and placed in metabolic cages according to replicates and treatment groups. A known quantity of feed (120g/ bird/ day and $200 \mathrm{~g} / \mathrm{bird} /$ day) for starter and finisher respectively of their respective diets was given and daily feed consumption was noted. The first three days were used to condition birds for the new environment of cage housing, feeding and drinking system. Thereafter, total fecal collection was made for three days by means of clean plastic trays placed under the cages. Fecal samples collected were oven dried to constant weight at $60^{\circ \mathrm{c}}$. Proximate analysis was carried out accordingly to AOAC (1984) and results obtained were used to calculate apparent nutrient digestibility according to Maynard et al. (1981) as shown below.

\section{Nutrient Digestibility $=$}

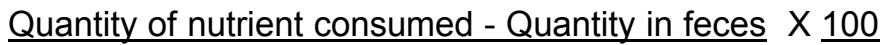
Quantity of nutrient consumed

\section{Hematological Study}

Blood collection was by bleeding through the bronchial vein. Syringe was used to collect blood into bottles containing dipotassium salt of Ethylenediaminetetra acetic acid (EDTA) and agitated to mix well. This was to prevent coagulation. Blood was collected from birds at the end of each phase and analysis for red blood cells (RBC) and white blood cells (WBC) according to Maxwell (1981). The quantity of heamoglobin ( $\mathrm{Hb})$ and packed cell volume (PCV) were respectively determined by cyanmet haemoglobin and micro haemotocrit methods (Dacie and Lewis, 1995).

\section{Data Analysis}

All data collected and calculated were subjected to Analysis of variance according to Steel and Torrie (1981).Least significant different was used to separate significant means.

\section{RESULTS AND DISCUSSION}

Proximate composition and amino acid profile of the blood meal table 1 shows $80.35 \%$ protein and $7.05 \%$ lysine which are similar to Olomu (1995) and Donkoh et al. (1999) respectively. Nutrients content of diets table 2 are similar to Olomu (1995). Influence of diets on nutrients digestibility and hematological parameters as shown in Table 3 for both starter and finisher phases indicates that significant difference occurred only for nutrients digestibility. During starter phase, diet significantly $(P<0.05)$ influenced protein digestibility, as blood meal negatively affected protein digestibility. Synthetic lysine group had better protein digestibility than birds feed 3.0 and $4.0 \%$ blood meal, but similar to 1.0 and $2.0 \%$ blood meal groups. Hence, synthetic lysine group was $6.7 \%$ better than $3.0 \%$ blood meal group and $7.09 \%$ in superiority than $4.0 \%$ blood meal group. Though there was no significant difference $(P>0.05)$ in other nutrients digestibility, synthetic lysine group marginally performed better than blood meal groups except for energy utilization. At finisher phase only protein digestibility still remained significantly $(P<0.05)$ different. However, considering the same protein digestibility, dietary influence changed. Though synthetic lysine group performed better $(75.39 \%)$ than $4.0 \%$ blood meal $(68.57 \%)$ it was similar $(P>0.05)$ to $3.0 \%$ blood meal group (70.01). This showed some level of adaptation. Therefore it seems that protein in blood meal was better utilized during finisher than starter phase. It was closely observed that in both phases, there was somehow marginal but progressive decline in digestibility showing some level of influence of blood meal level within blood meal groups. It was also observed that digestibility was higher at finisher than starter phase, which agrees with Maynard et al. (1981) that older animals digest nutrients better than younger animals. This work agrees with Edney et al.(2005) and later concurred by Khawaja et al.(2007) that blood meal reduced protein digestion at $4 \%$ inclusion level and above. Hurell (1990) attributed this to effect of maillard reaction due to heat of processing of blood meal.A look at the hematological parameters, show that there was no significant difference $(P>0.05)$ for both phases. Values of parameters shows a pattern that indicates diet having no influence on the hematological parameters hence blood meal may have had no deleterious effect on birds. This agrees with Donkoh et al. (1999) who reported that $2.5-7.5 \%$ blood meal inclusion in broiler diets did not alter the composition of red blood cells, white blood cells, hemoglobin and packed cell volume. There were high values of hematological parameters at finisher than starter phase in consonant with Olusanya (1977) who reported hematological parameters of animals to increase with age.

In conclusion, the result of this study indicates that blood meal in diets for broilers can reduce protein digestibility at $4.0 \%$ level at both starter and finisher phases and 
$3.0 \%$ at only starter phase. This however, may be deduced from the fact that heat of processing might have affected negatively the protein quality, and also that crude protein from $4.0 \%$ blood meal constituted 13.50 and $15.45 \%$ of the protein of the diet for starter and finisher respectively. Nevertheless, $3.0 \%$ blood meal could be used in diets for broiler chickens in place of $0.10 \%$ synthetic lysine if protein digestibility is to be considered.

\section{ACKNOWLEDGEMENT}

We appreciate the contributions of Prof. A .B .I. Udedibie.

Table 1: Proximate Composition and Amino Acid Profile of Processed Blood Meal

\begin{tabular}{ll}
\hline Composition & $\%$ \\
\hline Moisture & 8.67 \\
Dry matter & 91.33 \\
Crude protein & 80.35 \\
Crude fibre & 1.80 \\
Ether extract & 2.00 \\
Ash & 5.00 \\
Nitrogen free extract & 2.17
\end{tabular}

\section{Amino Acids}

Lysine

Arginine

Methionine

Histidine

Phenylalanine

Leucine

Isoleucine

Tryptophan

Threonine

Alanine 


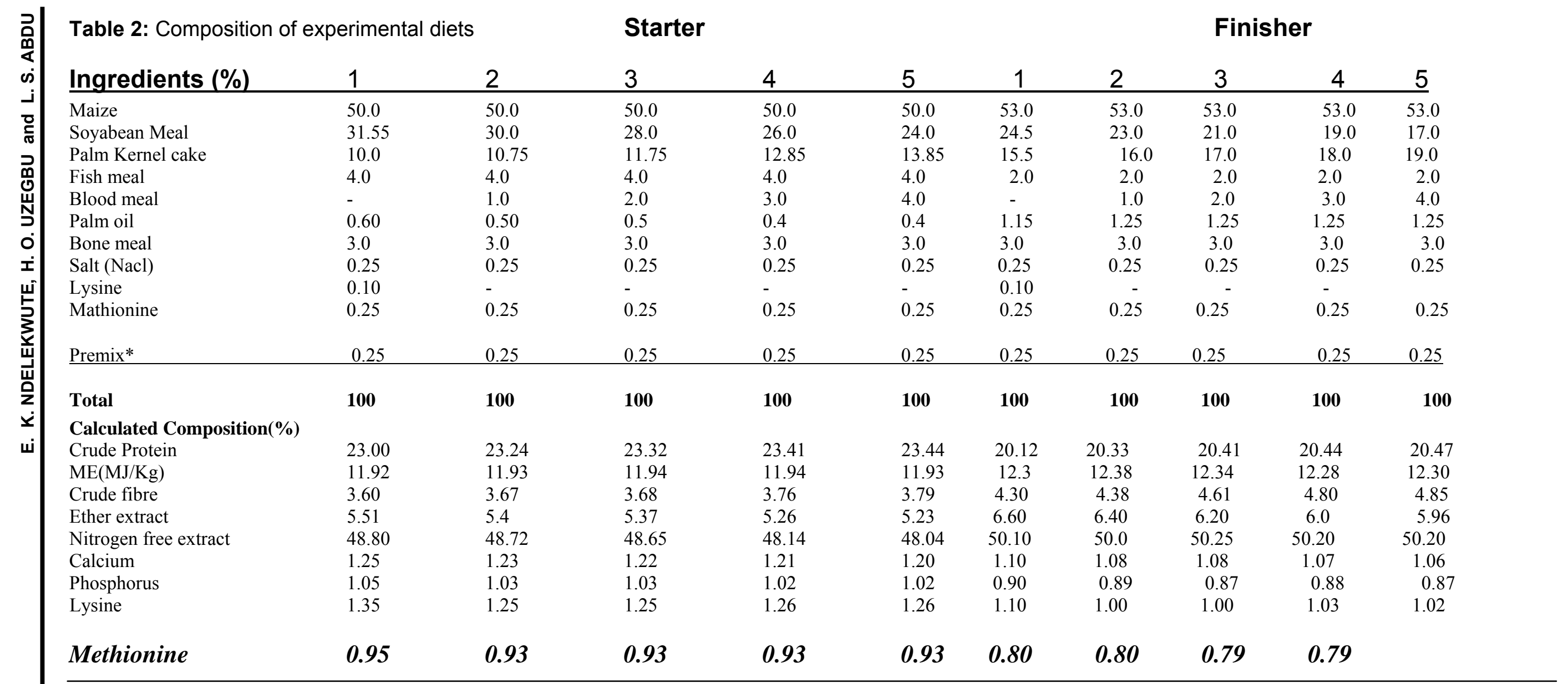

*Permix supplied (per kg diet) Vitamin A (15,000 IU), Vitamin D3 (3,000 IU),Vitamin E (30 I U), Vitamin K (2.5mg), Thiamin (2.0mg), Riboflavin (6mg), Pyridoxine (4mg), Niacin (40mg), Cobalamin (0.02mg), Pantothemic acid (910mg), Folic acid $(1.0 \mathrm{mg})$, Biotin $(0.08 \mathrm{mg})$, Chlorine chloride $(0.05 \mathrm{mg})$, Manganese $(0.096 \mathrm{~g})$, Zinc $(0.6 \mathrm{~g})$, Iron $(0.024 \mathrm{~g})$, Copper $(0.006 \mathrm{~g})$, Iodine $(0.0014 \mathrm{~g})$, Selenium $(0.24 \mathrm{mg})$, Cobalt $(0.024 \mathrm{mg})$, Antioxidant $(0.125 \mathrm{~g})$.
*Permix supplied (per kg diet), Vitamin A (10,000I.U), Vitamin D3 (2,00I.U), Vitamin E (20 IU), Vitamin K (2.0mg) Thiamin $(2.0 \mathrm{mg})$, Riboflavin $(3.0 \mathrm{mg})$, Pyridoxine $(4.0 \mathrm{mg})$, Niacin $(20 \mathrm{mg})$, Cobalamin $(0.05 \mathrm{mg})$, Panothemic acid $(5.0 \mathrm{mg})$, Folic acid $(0.5 \mathrm{mg})$, Biotin $(0.08 \mathrm{mg})$, Chlorine chloride $(0.2 \mathrm{~g})$, Manganese $(0.006 \mathrm{~g})$, Zinc $(0.03 \mathrm{~g})$, Iron $(0.05 \mathrm{~g})$, Copper $(0.006 \mathrm{~g})$ Iodine $(0.0014 \mathrm{~g})$, Selenium $(0.24 \mathrm{mg})$, Cobalt $(0.25 \mathrm{mg})$, Antioxidant $(0.125 \mathrm{~g})$. 
Table 3: Effects of dietary treatments on nutrients digestibility and hematological Parameters.

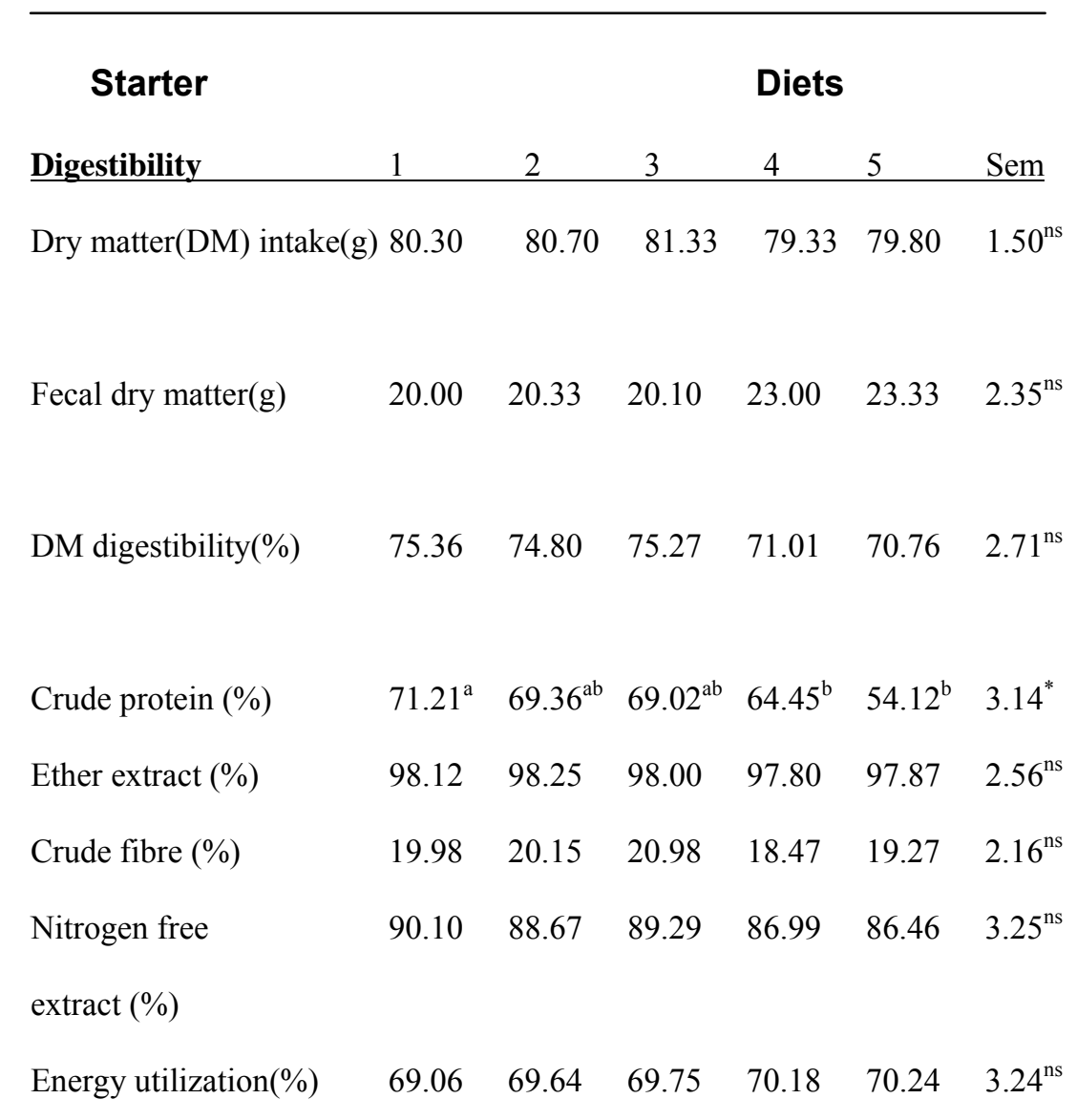

\section{Finisher}

Dry matter intake(g) $\quad 144.60 \quad 145.20 \quad 143.70 \quad 143.10 \quad 141.90 \quad 10.15^{\text {ns }}$

Fecal dry matter $(\mathrm{g}) \quad 27.60 \quad 30.00 \quad 30.00 \quad 30.50 \quad 31.20 \quad 3.12^{\text {ns }}$

$\begin{array}{lllllll}\text { DM digestibility(\%) } & 81.67 & 79.93 & 79.12 & 78.69 & 77.45 & 3.84^{\mathrm{ns}}\end{array}$

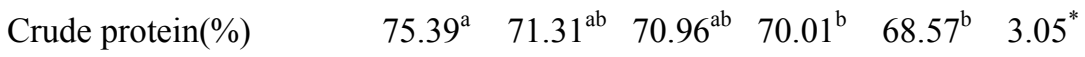

$\begin{array}{lllllll}\text { Ether extract }(\%) & 93.68 & 93.53 & 93.85 & 93.91 & 93.71 & 3.86^{\text {ns }}\end{array}$

\begin{tabular}{lllllll} 
Crude fibre (\%) & 34.67 & 32.23 & 31.73 & 31.00 & 30.44 & $2.23^{\text {ns }}$ \\
\hline
\end{tabular}

*Means along the row with different superscripts are significantly different $(P<0.05)$

\section{REFERENCES}

Awonorin, S.O., Ekpe, E. and Oyewole, I.O. 1991. Production of livestock feed from livestock wastes. J. Agric. Sci.\& Tech. 1 (2) : 104 - 108.

Akinnwande, A. I. and Braggs, D. B. 1986. Effects of the level of dietary lysine turnover rate of liver protein in the chick. Poult. Sci. 64:1938 - 1940.
AOAC.,1984. Official Methods of Anlysis. $14^{\text {th }}$ ed. Washington D.C. USA.

.Austic, R. E. and Neshein, M. C., 1990. Poultry Production. $3^{\text {rd }}$ ed. Lea and Febiger, London.

Dacie, J. V. and Lewis, S. M., 1975. Practical Hematology $5^{\text {th }}$ ed. Churchill Livington, Edinbourgh. 
D'Mello, J. P. F. 1993. Amino acids supplementation of cereal based diets for non- ruminants. Anim. Feed Sci. \& Tech. $45: 1-18$.

Donkoh, A., Atuahene, C. C., Anang D. M. and Ofori, S. K., 1999. Chemical composition of solar dried blood meal and its effect on performance of broiler chickens. Anim feed Sci. \& Tech. 81:299-307.

Edney, M. S., De Stefani, M. V. and Vidotti, R. M. 2005. Apparent digestibility of different ingredients in diets for bullfrog rane catesbeiana tadpoles. J. World Aquacult. 249 : 335-338

Hurell, R. F. 1990 .Influence of maillard reaction in nutritional foods. In :The maillard reaction in food processing, nutrition and physiology.

Birkhauser Verlag, Basel, Switzerland. 245 258.

Khawaja, T., Khan, S. H. and Ansari, N. N. 2007. Effect of different levels of blood meal on broiler performance during two phases of growth. Int. J Poult. Sci. 6 (12) : 860-866.

Kino, K. and Okumura, J., 1986. The effect of single essential amino acid deprivation on chick growth and nitrogen and energy balances at ad libitum and equalized food intakes. Poult. Sci 65:17281735.

Maxwell, M. H., 1981. Production of Heinz body anemia in the domestic fowl after ingestion of dimethyl disulphate: A hematological and ultra-structural study. Res Vet. Sci. 30:233-238.

Maynard, L A., Loosli J. K., Hintz, H. F. and Warner, R. G., 1981. Animal Nutrition. $7^{\text {th }}$ ed. Tata McGraw - Hill Pub. C. New Delhi, India.
Ndelekwute, E. K., 2004. Bioeconomics and evaluation of blood meal as a substitute for synthetic lysine in broiler diets. M.Sc. Thesis, Michael Okpara Univ. Agric., Umudike, Nigeria.

Obiorah, F. C., 1992. A. Guide to Poultry Production in the Tropics. $1^{\text {st }}$ ed. Ecena Pub. Enugu, Nigeria.

Odukwe, C. A. and Njoku, P. C.1987. Evaluation of blood meal and its potentials as a supplementary source of lysine laying chickens diets. J. Anim. Prod. Res. 7(1): 7-18.

Olomu, J. M., 1995. Monogastric Animal Nutrition: Principles and Practice. Jachem Pub. Nigeria.

Olusanya, S. K., 1977. Seasonal Variation in the levels of Some chemical and hematological components in the blood of white Fulani cows in Western Nigeria Nig. J. Anim. Prod. 2(4): 11-17.

Prieto, C., Aquilera, J. F., Lachica, M., Fernandez, F. I. and Perez, I., 1994. The use of Plasma free amino acid for predicting the limiting amino acid(s) in diets for chickens. Anim Feed Sci. \& Tech. 47:151164.

Steel, R. G. D. and Torrie, J. H., 1981. Principles and Procedures of Statistics McGraw-Hill Int. Books Co. Sydney

Uzegbu, H. O., Ndelekwute, E. K. and Abdu, L. S., 2007. Effect of inclusion of bambara groundnut (voandzeia subtenea) waste meal on the metabolisable energy and protein of broiler chickens. Proc. 41th Conf. Agric. Soc. Nig. Zaria, Nigeria. 348-352. 